\title{
Correction to: Cavitation of water in hardened cement paste under short-term desorption measurements
}

\author{
Ippei Maruyama $\mathbb{~}$ · Jiří Rymeš $\cdot$ Matthieu Vandamme $\cdot$ Benoit Coasne
}

Published online: 12 December 2019

(C) The Author(s) 2019

\section{Correction to: Materials and Structures (2018) 51:159 https://doi.org/10.1617/s11527-018-1285-x}

The article "Cavitation of water in hardened cement paste under short-term desorption measurements", written by "Ippei Maruyama, Jiří Rymeš, Matthieu Vandamme, Benoit Coasne", was originally published electronically on the publisher's internet portal (currently SpringerLink) on 26 November 2018 without open access.

The copyright of the article changed in December 2019 to (C) The Author(s) 2019, and the article is forthwith distributed under the terms of the Creative Commons Attribution 4.0 International License (http://creativecommons.org/licenses/by/4.0/), which permits use, duplication, adaptation, distribution and reproduction in any medium or format, as long as you give appropriate credit to the original author(s) and the source, provide a link to the Creative Commons license and indicate if changes were made.

Open Access This article is distributed under the terms of the Creative Commons Attribution 4.0 International License (http:// creativecommons.org/licenses/by/4.0/), which permits unrestricted use, distribution, and reproduction in any medium, provided you give appropriate credit to the original author(s) and the source, provide a link to the Creative Commons license, and indicate if changes were made.

Publisher's Note Springer Nature remains neutral with regard to jurisdictional claims in published maps and institutional affiliations.
The original article can be found online at https:// doi.org/10.1617/s11527-018-1285-x.

I. Maruyama $(\bowtie) \cdot J$. Rymeš

Graduate School of Environmental Studies, Nagoya

University, Nagoya, Japan

e-mail: ippei@dali.nuac.nagoya-u.ac.jp

M. Vandamme

Laboratoire Navier, UMR 8205, École des Ponts

ParisTech, IFSTTAR, CNRS, Champs-sur-Marne, France

B. Coasne

Univ. Grenoble Alpes, CNRS, LIPhy, 38000 Grenoble,

France 